\title{
STRATEGI KEBERHASILAN USAHA DENGAN PENDEKATAN MOTIVASI USAHA SERTA KEMAMPUANUSAHA PADA INDUSTRI MIKRO, KECIL DAN MENENGAH (IMKM) MAKANAN RINGAN DI KOTA SERANG
}

\author{
Qodiatul Asrof Ramadoni ${ }^{1)}$,Endang Silaningsih ${ }^{2)}$ \\ Program Studi Management Fakultas Ekonomi Universitas Djuanda Bogor \\ Email : Qodiatulasrofr@gmail.com, endang.silaningsih@unida.ac.id \\ Correpondence author : endang.silaningsih@unida.ac.id
}

\begin{abstract}
This research aims at identifying the strategic of business succes through business motivation approach and entrepreneurship ability in snack's small-medium industries (SMIs) in Serang City. There were 50 SMIs sampled. The methods used in this research are survey method. The result showed that business motivation $\left(X_{1}\right)$ and entrepreneurship ability $\left(X_{2}\right)$ simultaneously influencing the business succes of snack's small-medium industries (SMIs) in Serang City (Y). Whereas, partially all the indicators give both positive and significant affect the business succes of snack's small-medium industries (SMIs) in Serang City. All the indicators have a contribution factor in this research. Based on Importance and Performance Analysis (IPA) there are three atributte that must be prioritised, which are is practical knowledge of design, processing, accounting, administration and idea, proud to be independet (capital and management), and profit.
\end{abstract}

Keywords : Business Success, Business Motivation and Entrepreneurship ability.

\section{ABSTRAK}

Penelitian ini bertujuan untuk mengetahui Strategi Keberhasilan Usaha Dengan Pendekatan Motivasi Usaha Serta Kemampuan Usaha Pada Industri Mikro, Kecil dan Menengah (IMKM) Makanan Ringan Kota Serang. Pengambilan sampel berjumlah 50 IMKM Makanan Ringan yang terdaftar pada Dinas Perindustrian, Perdagangan dan Koperasi Kota Serang. Metode yang digunakan dalam penelitian ini adalah metode survey. Hasil penelitian menunjukkan bahwa variabel motivasi usaha $\left(\mathrm{X}_{1}\right)$ dan kemampuan usaha $\left(\mathrm{X}_{2}\right)$ baik secara simultan maupun parsial berpengaruh terhadap keberhasilan usaha IKM makanan ringan di Kota Serang (Y). Selain itu, berdasarkan Importance and Performance Analysis (IPA) diidentifikasi tiga atribut yang harus diprioritaskan, seperti memiliki pengetahuan praktik dalam desain, pemrosesan, pembukuan, administrasi dan ide, rasa bangga dapat mandiri (permodalan dan manajemen), dan besar kecilnya laba.

Kata Kunci : Keberhasilan Usaha, Motivasi Usaha dan Kemampuan Usaha.

\section{PENDAHULUAN}

Di era globalisasi ini, persaingan perdagangan di pasar semakin kompetitif. Pasarpasar yang berada di dalam negeri dikuasai oleh negara-negara lain jika tidak mampu menjadi pencipta pasar. Industri mikro, kecil menengah berperan penting dan diharapkan mampu menjadi pencipta pasar baik dalam negeri maupun luar negeri. Untuk melaksanakan peran tersebut, IMKM harus mulai memperbaiki dan membenahi diri dengan menggerakkan daya saingnya.
Pertumbuhan IMKM saat ini tidak terlepas dari komitmen, kebijakan dan program pemerintah agar IMKM di Indonesia dapat bertumbuh, berkembang dan memiliki daya saing yang tinggi sehingga mampu berkompetisi dalam perekonomian pada saat ini. Perkembangan klaster IMKM merupakan amanat dari perpres No.28 Tahun 2008 tentang kebijakan Industri Nasional. Pada perpres No.28 tersebut dinyatakan ada 5 (lima) komoditi IMKM yang dikembangkan yaitu: makanan ringan, minyak atsiri, gerabah atau keramik hias, batu mulia dan perhiasan, serta garam rak-yat. 
Menurut Badan pusat Statistik (BPS) 2014 kriteria IMKM dilihat dari jumlah tenaga kerjanyha yaitu: untuk industri mikro jumlah tenaga kerjanya adalah 4 orang, industri kecil dengan tenaga kerja 5-19 orang, industri menengah jumlah tenaga kerja 20-99 oraang, jika jumlah tenaga kerja lebih dari 99 orang, termasuk kategori industri besar.

IMKM makanan ringan termasuk kelompok industri yang cukup progresif perkembangannya di Indonesia. Makanan ringan termasuk barang convinience dan non durable goods. Untuk klasifikasi industrinya sendiri makanan ringan masuk dalam IMKM. Menurut peraturan Menteri Perindustrian Republik Indonesia Tahun 2009 IMKM makanan ringan adalah maakanan hasil olah industri yang bukan merupakan makanan pokok, tetapi sebagai makanan selingan seperti aneka krupuk (udang, ikan, bawang), aneka kripik (kacang, pisang, nanggka, singkong, kentang dan sebagainya). Aneka kipang (kacang, jagung, ketan dan lain-lain) makanan ringan lainnya seperti chiki dan maknan ringan lainnya.

Peluang pengembangan IMKM makanan ringan di Indonesia terbuka sangat luas dikarenakan adanya dukungan faktor internal yang kuat seperti: (1) besarnya jumlah penduduk yang menjadi pasar produk industri makanan, (2) penghasilan masyarakat terus meningkat yang mendo-rong permintaan akan produk makanan olahan, (3) sebagian besar bahan baku pro-duksi dapat diperoleh didalam negeri, (4) cukup tersedianya tenaga kerja dengan upah relatif rendah dan (5) kapasitas produksi beberapa usaha industri makanan yang dapat ditingkatkan.

Kendala IMKM menurut Kementerian Perindustrian (2015) adalah pada rendahnya daya saing industri yang disebabkan penggunaan mesin atau peralatan yang tradisional, mengakibatkan rendahnya hasil olahan dan kualitas produk. Keterbatasan modal untuk investasi mesin dan peralatan produksi baru menjadi kendala utama bagi IMKM termasuk keterbatasan sumber daya manusia, legal aspek, hingga akses pasar. Sedangkan menurut Kementrian Koperasi Kendala terbesar adalah terdapat pada aspek permodalannya yakni mencapai $40,48 \%$ menunjukkan masih sangat membutuhkan peran langsung dari pemerintah kerna kondisinya tidak cukup mampu mengakses sumber pembiayaan untuk melakukan usaha bagi sektor mikro dan sumber daya untuk memperbesar kapasitas usaha bagi sektor kecil dan menengah. Oleh sebab itu peran kewirausahaan melalui motivasi usaha dan kemempauan usaha untuk mencapai keberhasilan usaha belum optimal.

Salah satu Provinsi Banten yang merupakan penghasil makanan ringan yaitu Kota Serang mrupakan penghasil makanan khas yang terus dikembangkan untuk bersaing dengan makanan yang lebih moderen bahkan maknaan yang diimpor dari luar negeri yang terus menerus meningkat pada akhir-akhir ini. Produk-produk yang dihasilkan adalah emping, kue satu, kerupuk baso ikan, gipang, aneka kripik, sate bandeng dan sebagainya.

Potensi IMKM Kota Serang dalam industri maknan ringan sangat bervariasi dan jumlahnya akan terus meningkat pada tahun berikutnya.hal ini sesuai dengan Visi Industri Nasional mengatakan untuk memilih produkproduk daerah (provinsi, kabupaten dan kota) untuk diolah dan didorong, sehingga bertumbuh dan maju menjadi kompetensi inti industri daerah dan menjadi tilang punggung perekonomian regional.

Oleh sebab itu sangat penting untuk mengetahui bagaimana strategi keberhasilan usaha dengan pendekatan motivasi usaha dan kemampuan usaha pada IMKM makana ringan Kota Serang. Sedangkan manfaatnya bagi pelaku IMKM serta Pemerintah Daerah sebagai bahan dalam rangka mengembangkan dan mempertimbangkan motivasi usaha dan kemampuan usaha untuk meningkatkan keberhasilan usaha, sehingga dapat menjadikan langkah-langkah selanjutnya dalam menghadapi persaingan saat ini.

\section{MATERI DAN METODE}

\section{Keberhasilan Usaha}

Keberhasilan usaha menurut Alifudin (2015), adalah perusahaan yang mampu menggalang kekuatan dan potensi dalam dirinya, sedangkan menurut Yuyus Suryana dan Kartib Bayu (2013) yang harus dilakukan dan diperhatikan untuk mencapai keberhasilan usaha adalah implementation (kemampuan mengimplementasikan gagasan), time (peman- 
faatan waktu efektif dan efisien), cost (pengelolaan biaya), process (melalui suatu proses), value (mengembangkan menciptakan nilainilai) dan standard (menentukan standar dari produk/jasa yang disediakan).

\section{Motivasi Usaha}

Motivasi usaha menurut Sunyoto (2012) merupakan sebuah dorongan yang tumbuh dalam diri seseorang. Sedangkan menurut Leonardus Saiman (2011) adalah : Laba (dapat menentukan beberapa laba rugi dan beberapa yang dibayarkan kepada pegawai), kebebasan (bebas mengatur waktu, intervensi, budaya organisasi), impian personal (bebas mencapai impian hidup yang diharapkan, tidak harus mengikuti keinginan oranag lain, menentukan nasibnya sendiri) dan kemandirian (memiliki rasa bangga karena dapat mandiri seperti permodalan, pengelolaan dan manajemen, mandiri dalam pengawasan, serta menjadi manajaer terhadap dirinya sendiri).

\section{Kemampuan Usaha}

Kemampuan usaha menurut Yuyun Wirasasmita dalam Suryana (2014) bahwa kemampuan usaha yakni: memiliki pengetahuan usaha (self knowledge), memilliki imajinasi atau khayalan (imagination), memiliki pengetahuan praktik (practica knowledge), memiliki keterampilan menemukan (search skill), memiliki pandangan kedepan (foresight), memiliki keterampilan menghitung (computation skill), serta memiliki keterampilan berkomunikasi (comunication skill).

\section{Pengaruh Motivasi Usaha dan Kemampuan Usaha Terhadap Keberhasilan Usaha}

Menurut Alifuddin (2015), keberhasilan usaha adalah mereka yang mampu menggalangkekuatan dan potensi dalam dirinya, sedangkan menurut Ranto dalam Dauly dan Ramadini (2013), keberhasilan berwirausaha tidaklah identik dengan bagaimana seseorang bisa mengumpulkan uang sehingga menghasilkan nilai tambah. Berusaha lebih dilihat dari bagaimana seseorang bisa membentuk, mendirikan, serta menjalankan usaha dari awal.

Merujuk dari pengertian keberhasilan atau sukses, maka dalam mengukup keberhasilan bagi wirausaha dapat dibuktikan oleh prestasi yang dicapai, yaitu pertumbuhan dari perusahaan yang dikelolanya. Pertumbuhan ini dibuktikan oleh penjualan, aset perusahaan, dan jumlah karyawan. Untuk meraih keberhasilan itu, tentunya mempunyai kiatkiat dalam menciptakan peluang usaha,karena tahap pemanfaatan dan pengembangan kesempatan sudah menjadi hal yang rutin. Ideide inovatif yang akan membantu dalam memotivasi pengusaha yang maju. Wawasan dan pengalaman praktis serta perilaku wirausaha serta motif prestasi dan keberhasilan akan mempengaruhi pengusahapengusaha lain.

Kinerja SDM dipengaruhi oleh kemampuan, motivasi dan keadaan lingkungannya. Kemampuan dapat diraih dari pendidikan, pelatihan dan pengalaman karena masalah motivasi SDM merupakan faktor penting dalam menunjang keberhasilan usaha. Motivasi merupakan rangsangan diri sendiri untuk melakukan tindakan. Pada umumnya setiap orang memiliki motivasi yang berbeda, motivasi bisa datang dari dirinya atau orang lain tergantung bagaimana cara menyikapi rangsangan tersebut agar menjadikan suatu tindakan yang positif.

\section{$\mathrm{H}_{1}$ : Terdapat pengaruh positif dan signi- fikan motivasi usaha dan kemampuan usaha terhadap keberhasilan usaha}

\section{Pengaruh Motivasi Usaha Terhadap Keberhasilan Usaha}

Menurut Irham Fahmi (2014) motivasi adalah perilaku usaha untuk memenuhi keinginan yang diinginkan. Motivasi merupakan proses psikologis yang mendasar dan merupakan unsur yang menjelaskan perilaku seseorang. Motivasi sendiri menjadi faktor penentu dalam pencapaian tujuan. Motivasi berhubungan dengan dorongan atau kekuatan yang berada dalam diri seseorang yang tidak dapat dilihat. David C. McClelland dalam Suryana (2014) berpendapat bahwa berwirausaha ditentukan oleh motif berprestasi, optimisme, sikap, nilai, dan keberhasilan. Keberhasilan wirausahawan ditentukan oleh perilaku kewirausahaan. Faktor yang memengaruhi perilaku kewirausahaan itu sendiri adalah internal factor dan external factor. Faktor-faktor internal meliputi: hak kepemilikan (property right-PR), kemampuan/kompetensi (competency/ability-C), dan 
insentif (incentive-I), sertaexternal factor meliputi: lingkungan (environment-E).
$\mathrm{H}_{2}$ : Terdapat pengaruh positif dan signifikan motivasi usaha terhadap keberhasilan usaha

\begin{tabular}{|c|}
\hline $\begin{array}{l}\text { Motivasi Usaha } \\
\text { - Laba } \\
\text { - Kebebasan } \\
\text { - Impian personal } \\
\text { - Kemandirian } \\
\text { (Sumber: Leonardus Saiman, 2011) }\end{array}$ \\
\hline $\begin{array}{l}\text { Kemampuan Usaha } \\
\text { - Memiliki Pengetahuan Usaha } \\
\text { - Memiliki Imajinasi atau Khayalan } \\
\text { - Memiliki Pengetahuan Praktik } \\
\text { - Memiliki Keterampilan } \\
\text { Menemukan } \\
\text { - Memiliki Pandangan Ke Depan } \\
\text { - Memiliki Keterampilan } \\
\text { Menghitung } \\
\text { - Memiliki Keterampilan } \\
\text { Berkomunikasi } \\
\text { (Sumber: Yuyun Wirasasmita dalam } \\
\text { Suryana, 2014) }\end{array}$ \\
\hline
\end{tabular}

kekuatan yang berada dalam diri seseorang yang tidak dapat dilihat. David C. McClelland dalam Suryana (2014) berpendapat bahwa berwirausaha ditentukan oleh motif berprestasi, optimisme, sikap, nilai, dan keberhasilan. Keberhasilan wirausahawan ditentukan oleh perilaku kewirausahaan. Faktor yang memengaruhi perilaku kewirausahaan itu sendiri adalah internal factor dan external

\section{Pengaruh Kemampuan Usaha Terhadap Keberhasilan Usaha}

Objek studi kewirausahaan menurut Suryana (2014) adalah kemampuan, sifat-sifat, nilai-nilai, dan kepribadian seseorang yang diwujudkan dalam perilaku.Untuk menjadi wirausahawan, harus memilik dasar berupa visi yang jelas, kemampuan dan komitmen yang kuat,kecukupan modal, baik uang maupun waktu, dan kecukupan tenaga serta fikiran. Modal-modal tersebut sebenarnya tidak cukup apabila tidak dilengkapi dengan kemampuan.

Dun Steinhoff \& John F. Burgess dalam Suryana (2014) mengatakan karakteristik yang diperlukan untuk mencapai pengembangan dan keberhasilan berwirausaha sebagai berikut: Pertama, untuk menjadi wirausahawan yang sukses, seseorang harus memiliki ide atau visi bisnis yang jelas serta kemauan dan keberanian untuk menghadapi risiko, baik berupa waktu maupun uang. Apabila ada kesiapan dalam menghadapi risiko.Kedua, bila ingin sukses harus membuat perencanaan usaha, mengorganisasikan, dan menjalankannya.Agar usahanya berhasil, selain harus bekerja keras sesuai dengan urgensinya, wirausahawan harus mampu mengembangkan hubungan, baik dengan mitra usaha maupun sesama pihak yang terkait dengan kepentingan perusahaan.Sukses dalam berwirausaha tidak diperoleh secara tiba-tiba atau instan dan secara kebetulan, tetapi dengan penuh perencanaan, memiliki visi, misi, kerja keras, dan memiliki keberanian secara bertanggung jawab.

\section{$\mathrm{H}_{3}$ : Terdapat pengaruh positif dan signifikan kemampuan usaha terhadap keberhasilan usaha}

Bentuk penelitiannya adalah deskriptif yaitu bertujuan untuk menguraikan karakteristik (sifat-sifat) tentang suatu keadaan 
(Supranto, 2001) dan verifikatif. Objek dalam penelitian ini adalah IMKM makanan ringan yang berlokasi di Kota Serang.

Metode penelitian adalah survey. Jenis data primer yang dibutuhkan yakni berupa informasi melalui wawancara kepala DISPERINDAGKOP Kota Serang dan kuesioner yang diberikan kepada peneglola usaha yang menjadi responden terpilih. Data skunder yang didapatkan dari menelaah buku dan data data yang didapatkan dari DISPERINDAGKOP Kota Serang. Untuk menjawab pernmasalahan, variabel yang akan dianalisis terdiri dari variabel bebas yaitu motivasi usaha $\left(\mathrm{X}_{1}\right)$ dan kemampuan usaha $\left(\mathrm{X}_{2}\right)$. Variabel terikat adalah keberhasilan usaha (Y).

Oleh karena skala Pengukuran variabel menggunakan skala ordinal yaitu skala yang menunjukkan perbedaan kategori satu dengan lainnya. Riduwan (2005) mengemukakan bahwa sebelum dilakukan pengujian dengan regresi berganda, perlu terlebih dahulu menggunakan skala pengukuran yaitu skala likert (1-5). Adapun Populasi yang diambil adalah IMKM di Kota Serang. Menurut Frankel dan Wallen (1993), unutk penelitian deskriptif jumlah sampel minimal yang akan diambil adalah 30 (tiga puluh) sampel. Untuk memenuhi syarat tersebut maka sampel yang diambil dalam peneliitan ini adalah 50 dampel dengan alasan subyektif (judgement) untuk penelitian ini yaitu: (1) IMKM; (2) jumlah tenaga kerja menurut Departemen Perindustrian dan Badan Pusat Statistik 2014. Maka pengunpulan data melalui penyebaran kuesioner sebanyak 50 pengelola usaha.

\section{Analisis Uji Validitas dan Reliabilitas Instrumen Penelitian}

Menurut Sugiyono (2013) Jika dari hasil diperoleh nilai hitung lebih besar atau sama dengan nilai ketetapan yakni $\geq 0,3$ maka data tersebut adalah valid berarti layak untuk digunakan dalam pengujian hipotesis, sedangkan jika nilai hitung lebih kecil dari nilai ketetapan yakni < 0,3 menunjukkan bahwa data tersebut tidak valid berarti tidak layak untuk digunakan dalam pengujian hipotesisi, setelah yang digunakan ini valid, maka dilanjutkan dengan uji reabilitas. Menurut Sugiyono (2013) adalah Uji reliabelitas untuk menunjukkan sejauh mana hasil pengukuran terhadap item-item pertanyaan apakah tetap konsisten atau tidak. Pengukuran konsistensi interval penggunaan instrument digunakan Cronbach Alpha, jika nilai variabel memiliki rata-rata sebesar 0,6 atau lebih dan uji reliabilitas menunjukkan kuesioner reliabel.

\section{Metode Analisis}

Data yang terkumpul dianalisis dengan cara deskriptif dan verifikatif dengan menggunakan uji statistik. Akan dianalisis secara deskriptif. Analisis regresi berganda menurut Sugiyono (2005) adalah alat untuk meramalkan nilai pengaruh dua variabel bebas atau lebih terhadap satu variabel terikat. Persamaan umum regresi berganda yaitu:

$$
\mathbf{Y}=\mathbf{a}+\boldsymbol{\beta}_{1} \mathbf{X}_{1}+\boldsymbol{\beta}_{2} \mathbf{X}_{2}+\varepsilon
$$

\section{Dimana :}

$$
\begin{aligned}
& \mathbf{Y} \quad=\text { Variabel terikat } \\
& \mathbf{X} \quad=\text { Variabel bebas } \\
& \text { a } \quad=\text { Konstanta } \\
& \boldsymbol{\beta}_{1}=\text { Koefisien regresi pengaruh } \\
& \text { faktorX } \mathrm{X}_{1} \text { terhadap } \mathrm{Y} \\
& \boldsymbol{\beta}_{2}=\text { Koefisien regresi pengaruh factor } \\
& \mathrm{X}_{2} \text { terhadap } \mathrm{Y} \\
& \varepsilon=\text { Faktor yang tidak diteliti }
\end{aligned}
$$

Untuk menguji hipotesis penelitian yang diajukan akan digunakan uji statistik dengan model penelitian adalah :

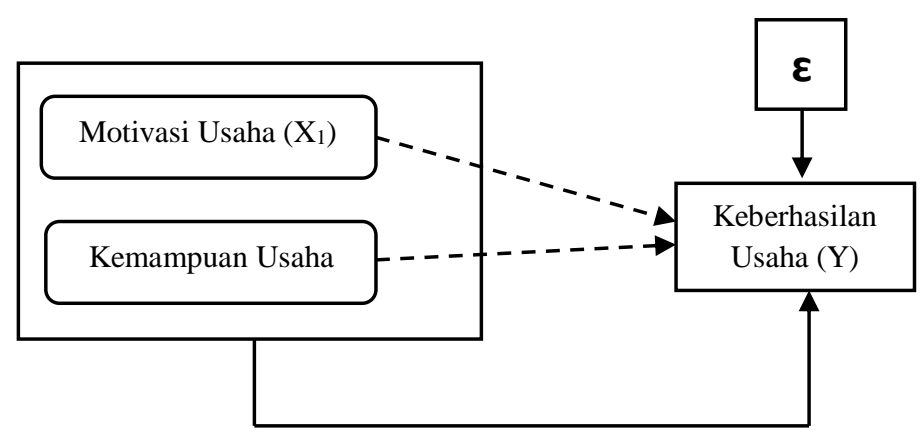

Gambar 2. Model Penelitian

Analisis Korelasi berganda Menurut Sugiyono (2004) korelasi ganda merupakan angka yang menunjukan arah dan kuatnya hubungan antara dua atau lebih variabel independen secara bersama-sama dengan satu variable dependen. Untuk mengetahui 
bagaimana hubungan antara motivasi usaha dan kemampuan usaha terhadap keberhasilan usaha IMKM makanan ringan di Kota Serang. Analisis Koefisien Determinasi digunakan untuk melihat besarnya kontribusi factor motivasi usaha dan kemampuan usaha terhadap keberhasilan usaha IMKM makanan ringan di Kota Serang

\section{Pengujian Hipotesis}

Untuk menguji signifikansi hubungan variable independen dengan variable dependen secara simultan maka di gunakan uji $F$ dengan tingkat signifikansi $(\alpha)=0,05$. Hubungan variabel independen secara parsial dengan variabel dependent, Untuk menguji apakah masing-masing variabel bebas berpengaruh positif dan signifikan terhadap variabel terikat secara parsial dengan tingkat signifikansi $\alpha=0,05$ dan juga penerimaan atau penolakan hipotesa maka di gunakan uji t.

\section{Analisis Importance and Performance Analysis (IPA)}

Alat analisis yang digunakan adalah metode IPA. Untuk mengetahui akibat mana yang harus diprioritaskan dengan membandingkan atribut lainnya, maka digunakan IPA atau analisis tingkat kepentingan/harapan (Setiawan, 2005).

\section{HASIL DAN PEMBAHASAN}

\section{Karakteristik Pemilik Usaha}

Mayoritas pelaku pemilik usaha pada IMKM Makanan Ringan Kota Serang berjenis kelamin laki-laki dengan jumlah 31 orang atau sebesar 62\%, dimana usia pengelola usaha 44-55 tahun dengan ju,lah 18 orang atau sebesar $36 \%$, menunjukkan bahwa usia yang produktif dalam berwirausaha adalah padausia 44-55 tahun, karena menurut UU No.13 tahun 2003 tentang Tenaga Kerja di katakan masa usia produktif adalah 15-64 tahun. Adapun pendidikan terakhir pemilik usaha adalah SD \& SMU dengan jumlah 28 orang atau sebesar $56 \%$ menunjukkan dengan berwirausaha tidak memerlukan pendidikan yang tinggi akan tetapi memerlukan keberanian dalam menerima resiko. Dan lama usaha yang dijalaninya > 10 tahun dengan jumlah 20 orang atau sebesar $40 \%$ bahwa pemilik usaha sudah berpengalaman dalam menjalankan usahanya. Sedangkan jumlah tenaga kerja 4-19 orang adalah 42 orang atau sebesar $84 \%$, menunjukkan usaha IMKM makanan ringan termasuk usaha kecil karena melihat dari investasi atau modal yang masih kecil serta SDM yang relatif sedikit.

\section{Motivasi Usaha Pada IMKM Makanan Ringan Kota Serang}

Adapun rekapitulasi tanggapan pemilik usaha terhadap motivasi usaha pada IMKM makanan ringan Kota Serang meliputi penilaian dan harapan sebagai berikut:

Tabel 1. Hasil Penggabungan dan Modifikasi

\begin{tabular}{|c|c|c|c|}
\hline No. & Uraian & $\begin{array}{c}\text { Penilaian } \\
\text { Pemilik } \\
\text { Usaha }\end{array}$ & Ket \\
\hline 1 & $\begin{array}{l}\text { Besar kecilnya } \\
\text { laba }\end{array}$ & 3,44 & Tinggi \\
\hline 2 & $\begin{array}{l}\text { Kebebasan } \\
\text { mengatur usaha }\end{array}$ & 3,74 & Baik \\
\hline 3 & $\begin{array}{l}\text { Kebebasan } \\
\text { mencapai } \\
\text { keberhasilan }\end{array}$ & 3,82 & Baik \\
\hline 4 & $\begin{array}{l}\text { Rasa bangga } \\
\text { dapat } \\
\text { mandiri(permod } \\
\text { alan } \\
\text { \&Manajemen) }\end{array}$ & 3,64 & Baik \\
\hline \multicolumn{2}{|c|}{$\begin{array}{l}\text { Rata-rata penilaian } \\
\text { motivasi usaha }\left(X_{1}\right)\end{array}$} & 3,66 & Tinggi \\
\hline
\end{tabular}

Rata-rata tanggapan pemiıк usana ternadap penilaian motivasi usaha pada IMKM makanan ringan Kota Serang adalah 3,66 dengan interprestasi tinggi, menunjukkan motivasi usaha pada IMKM makanan ringan sudah memenuhi yang diinginkan.

Tabel 2. Rekapitulasi Harapan Untuk Variabel Motivasi Berusaha $\left(\mathrm{X}_{1}\right)$

\begin{tabular}{clcc}
\hline No. & Uraian & $\begin{array}{c}\text { Penilaian } \\
\text { Responden }\end{array}$ & Keterangan \\
\hline 1 & $\begin{array}{l}\text { Besar kecilnya } \\
\text { laba }\end{array}$ & 4,04 & Tinggi \\
\hline
\end{tabular}




\begin{tabular}{|c|c|c|c|}
\hline 2 & $\begin{array}{l}\text { Kebebasan } \\
\text { mengatur usaha }\end{array}$ & 3,94 & Tinggi \\
\hline 3 & $\begin{array}{l}\text { Kebebasan } \\
\text { mencapai } \\
\text { keberhasilan }\end{array}$ & 4,10 & Tinggi \\
\hline 4 & $\begin{array}{l}\text { Rasa bangga dapat } \\
\text { mandiri } \\
\text { (permodalan dan } \\
\text { Manajemen) }\end{array}$ & 4,08 & Tinggi \\
\hline \multicolumn{2}{|c|}{$\begin{array}{l}\text { Rata-rata harapan } \\
\text { motivasi usaha }\left(\mathrm{X}_{1}\right)\end{array}$} & 4,04 & Tinggi \\
\hline \multicolumn{4}{|c|}{$\begin{array}{l}\text { Rata-rata tanggapan pemilik usaha } \\
\text { terhadap harapan motivasi usaha pada IMKM } \\
\text { makanan ringan Kota Serang adalah } 4,04 \\
\text { dengan interprestasi tinggi, menunjukkan } \\
\text { pemilik usaha masih ingin meningkatkan } \\
\text { motivasi usaha untuk mencapai keberhasilan } \\
\text { usaha. }\end{array}$} \\
\hline
\end{tabular}

\section{Kemampuan Usaha Pada IMKM Makanan Ringan Kota Serang}

Rekapitulasi tanggapan pemilik usaha terhadap keamampuan usaha pada IMKM makanan ringan Kota Serang terdiri dari penilaian dan harapan. Rata-rata tanggapan pemilik usaha terhadap penilaian kemampuan usaha pada IMKM makanan ringan Kota Serang adalah 3,63 dengan interprestasi tinggi, menunjukkan bahwa pemilik usaha memandang kemampuan berusaha sebagai aspek yang penting untuk diperhatikan (lihat tabel 3).

Tabel 3. Rekapitulasi Penilaian Untuk Variabel Kemampuan Usaha $\left(\mathrm{X}_{2}\right)$

\begin{tabular}{|c|c|c|c|}
\hline No. & Uraian & $\begin{array}{l}\text { Penilaian } \\
\text { Responden }\end{array}$ & Keterangan \\
\hline 1 & $\begin{array}{l}\text { Pengetahuan } \\
\text { usaha }\end{array}$ & 3,60 & Tinggi \\
\hline 2 & Imajinasi dan ide & 3,76 & Tinggi \\
\hline 3 & $\begin{array}{l}\text { Pengetahuan } \\
\text { praktik dalam } \\
\text { disain, } \\
\text { pemrosesan, } \\
\text { pembukuan, } \\
\text { administrasi dan } \\
\text { pemasaran }\end{array}$ & 3,44 & Tinggi \\
\hline 4 & Kreatif & 3,54 & Baik \\
\hline 5 & Prediksi & 3,66 & Tinggi \\
\hline 6 & $\begin{array}{l}\text { Keterampilan } \\
\text { berhitung }\end{array}$ & 3,80 & Baik \\
\hline 7 & $\begin{array}{l}\text { Keterampilan } \\
\text { berkomunikasi }\end{array}$ & 3,56 & Baik \\
\hline \multicolumn{2}{|c|}{$\begin{array}{l}\text { Rata-rata penilaian } \\
\text { kemampuan usaha }\left(\mathrm{X}_{2}\right)\end{array}$} & 3,63 & Tinggi \\
\hline
\end{tabular}

Sementara itu, rata-rata tanggapan pemilik usaha terhadap harapan kemampuan usaha pada IMKM makanan ringan Kota Serang adalah 3,92 dengan interpretasi tinggi. Ini menunjukkan bahwa pemilik usaha masih ingin meningkatkan kemampuan usahanya untuk dapat mencapai keberhasilan usaha dengan maksimal. Nilai tertinggi ada pada uraian pengetahuan usaha dan prediksi yang masing-masingnya sebesar 3,90. Ini berarti bahwa pelaku usaha yang menjadi responden memandang penting aspek pengetahuan usaha sebagai dasar untuk untuk melakukan proyeksi atau prediksi atas kecenderungan pasar.

Tabel 4. Rekapitulasi Harapan Untuk Variabel Kemampuan Usaha $\left(\mathrm{X}_{2}\right)$

\begin{tabular}{|c|c|c|c|}
\hline No. & Uraian & $\begin{array}{l}\text { Penilaian } \\
\text { Responden }\end{array}$ & Keterangan \\
\hline 1 & $\begin{array}{l}\text { Pengetahuan } \\
\text { usaha }\end{array}$ & 3,90 & Tinggi \\
\hline 2 & Imajinasi dan ide & 4,26 & $\begin{array}{l}\text { Sangat } \\
\text { Tinggi }\end{array}$ \\
\hline 3 & $\begin{array}{l}\text { Pengetahuan } \\
\text { praktik dalam } \\
\text { disain, } \\
\text { pemrosesan, } \\
\text { pembukuan, } \\
\text { administrasi dan } \\
\text { pemasaran }\end{array}$ & 3,88 & Tinggi \\
\hline 4 & Kreatif & 3,80 & Tinggi \\
\hline 5 & Prediksi & 3,90 & Tinggi \\
\hline 6 & $\begin{array}{l}\text { Keterampilan } \\
\text { berhitung }\end{array}$ & 3,84 & Tinggi \\
\hline 7 & $\begin{array}{l}\text { Keterampilan } \\
\text { berkomunikasi }\end{array}$ & 3,86 & Tinggi \\
\hline \multicolumn{2}{|c|}{$\begin{array}{l}\text { Rata-rata harapan } \\
\text { kemampuan usaha }\left(\mathrm{X}_{2}\right)\end{array}$} & 3,92 & Tinggi \\
\hline
\end{tabular}

\section{Keberhasilan Usaha Pada IMKM Makanan Ringan Kota Serang}

Adapun rekapitulasi tanggapan pemilik IMKM terhadap keberhasilan usaha pada IMKM makanan ringan Kota Serang terdiri dari penilaian dan harapan.

Tabel 5. Rekapitulasi Penilaian Untuk Variabel Keberhasilan Usaha (Y)

\begin{tabular}{clcc}
\hline No. & Uraian & $\begin{array}{c}\text { Penilaian } \\
\text { Responden }\end{array}$ & Keterangan \\
\hline 1 & $\begin{array}{l}\text { Kemampuan \& } \\
\text { keberanian }\end{array}$ & 3,58 & Baik
\end{tabular}




\begin{tabular}{clcc}
2 & $\begin{array}{l}\text { Waktu efektif \& } \\
\text { efesien }\end{array}$ & 3,54 & Baik \\
3 & Pengelolaan biaya & 3,46 & Baik \\
\hline 4 & $\begin{array}{l}\text { Menjalankan } \\
\text { usaha melalui } \\
\text { suatu proses }\end{array}$ & 4,04 & Baik \\
5 & $\begin{array}{l}\text { Menjalankan } \\
\text { usaha dengan } \\
\text { mengembangkan } \\
\text { \& menciptakan } \\
\text { nilai-nilai etos } \\
\text { kerja } \\
\text { Menentukan } \\
\text { standar dari } \\
\text { produk }\end{array}$ & 3,78 & Baik \\
\hline $\begin{array}{l}\text { Rata-rata nilai } \\
\text { keberhasilan usaha (Y) }\end{array}$ & 3,64 & Baik \\
\hline
\end{tabular}

Rata-rata tanggapan pemilik usaha terhadap penilaian keberhasilan usaha pada IMKM maknan ringan Kota Serang adalah 3,67 dengan interprestasi baik, menunjukkan pemilik usaha sudah mencapai yang ingin mereka capai dan mereka inginkan.

Tabel 6. Rekapitulasi Harapan Untuk Varibel Keberhasilan Usaha (Y)

\begin{tabular}{|c|c|c|c|}
\hline No. & Uraian & $\begin{array}{l}\text { Penilaian } \\
\text { Responden }\end{array}$ & Keterangan \\
\hline 1 & $\begin{array}{l}\text { Kemampuan \& } \\
\text { keberanian }\end{array}$ & 4,10 & Tinggi \\
\hline 2 & $\begin{array}{l}\text { Waktu efektif \& } \\
\text { efesien }\end{array}$ & 3,86 & Tinggi \\
\hline 3 & Pengelolaan biaya & 3,82 & Tinggi \\
\hline 4 & $\begin{array}{l}\text { Menjalankan } \\
\text { usaha melalui } \\
\text { suatu proses }\end{array}$ & 4,34 & $\begin{array}{l}\text { Sangat } \\
\text { Tinggi }\end{array}$ \\
\hline 5 & $\begin{array}{l}\text { Menjalankan } \\
\text { usaha dengan } \\
\text { mengembangkan } \\
\text { \& menciptakan } \\
\text { nilai-nilai etos } \\
\text { kerja }\end{array}$ & 4,10 & Tinggi \\
\hline 6 & $\begin{array}{l}\text { Menentukan } \\
\text { standar dari } \\
\text { produk }\end{array}$ & 4,24 & $\begin{array}{l}\text { Sangat } \\
\text { Tinggi }\end{array}$ \\
\hline $\begin{array}{l}\text { Rat } \\
\text { keb }\end{array}$ & $\begin{array}{l}\text { ta nilai harapan } \\
\text { asilan usaha (Y) }\end{array}$ & 4,08 & Tinggi \\
\hline
\end{tabular}

Rata-rata tanggapan pemilik usaha terhadap tingkat harapan keberhasilan usaha pada IMKM makanan ringan Kota Serang adalah 4,08 dengan interprestasi Tinggi, menunjukkan pemilik usaha masih ingin untuk meningkatkan keberhasilan usaha agar dapat memenuhi kebeutuhan yang mereka inginkan.

\section{Hasil Estimasi Persamaan Regresi}

Bentuk persamaan diperhitungkan dengan analisis regresi berganda. Adapun persamaan tersebut adalah untuk menunjukan pengaruh variabel bebas terhadap variabel terikat. Berdasarkan hasil penelitian, diperoleh suatu persamaan regresi sebagai berikut:

\section{$Y=15.133+0,743 X_{1}+0,561 X_{2}+e$}

Berdasarkan persamaan tersebut, motivasi usaha dan kemampuan usaha berpengaruh positif terhadap keberhasilan usaha. Dari persamaan regresi diketahui bahwa motivasi usaha $\left(\mathrm{X}_{1}\right)$ dan kemampuan usaha $\left(\mathrm{X}_{2}\right)$ berpengaruh positif terhadap keberhasilan usaha (Y). Adapun hubungan antara $\mathrm{X}_{1}$ dan $\mathrm{X}_{2}$ terhadap $\mathrm{Y}$ yang menunjukan angka korelasi 0,839 , berarti bahwa hubungan di antara variabel sangat kuat. Artinya, semakin tinggi motivasi usaha dan kemampuan usaha maka keberhasilan usaha IMKM makanan ringan Kota Serang semakin meningkat. Selain itu diketahui juga besarnya pengaruh variabel independen terhadap variabel dependen secara simultan dari nilai R Square, yang menunjukkan bahwa motivasi usaha dan kemampuan usaha mempu menjelaskan sebesar $70,9 \%$ terhadap peningkatan keberhasilan usaha. Besarnya faktor-faktor lain yang tidak diteliti sebesar $29,1 \%$.

\section{Pengujian Koefesien Regresi Simultan (Uji} F)

Melihat pengaruh secara simultan variabel $\mathrm{X}_{1}$ dan $\mathrm{X}_{2}$ terhadap $\mathrm{Y}$, digunakan statistik uji-F dengan hipotesis statistik sebagai berikut:

Ho $: \beta \mathrm{i} \leq 0$ :Tidak terdapat pengaruh secara simultan faktor motivasi usaha (X1) dan kemampuan usaha (X2) terhadap keberhasilan usahaIMKM (Y)

$\mathrm{Ha}: \beta i>0$ :Terdapat pengaruh secara simultan faktor motivasi usaha (X1) dan kemampuan usaha (X2) terhadap keberhasilan usaha IMKM (Y).

Untuk menguji hipotesis statistik di atas digunakan statistik uji-F. Diperoleh nilai Fhitung sebesar 26,245 dan nilai Ftabel untuk 
$\alpha=0,05$ dengan derajat kebebasan $\mathrm{V} 1=3$ $1=2$ dan $\mathrm{V} 2=50-2-1=47$ sebesar 3,20 yang dimana bisa dilihat bahwa Fhitung $>$ Ftabel $(26.245>3,20)$ sehingga dapat disimpulkan, H0 ditolak dan Ha diterima dengan tingkat kepercayaan $95 \%$. Ini artinya, variabel independen motivasi usaha (X1) dan kemampuan usaha (X2) berpengaruh positif dan signifikan secara simultan (bersama-sama) terhadap keberhasilan usaha IMKM Kota Serang (Y). Hal ini seperti yang dikemukakan Suryana (2011) bahwa menjadi wirausaha sukses (keberhasilan usaha) harus memiliki bussines vision yang jelas, kemudian ada kemauan dan keberanian untuk menghadapi risiko baik waktu maupun uang.

\section{Pengujian Koefesien Regresi Parsial (Uji t)}

Dari perhitungan diperoleh hasil pengujian untuk pengaruh secara masingmasing setiap variabel $\mathrm{X}_{1}$ dan $\mathrm{X}_{2}$ terhadap $\mathrm{Y}$ sebagi berikut:

\section{a) Pengaruh Motivasi Usaha ( $\left.\mathbf{X}_{1}\right)$ \\ Terhadap Keberhasilan Usaha (Y)}

Untuk melihat pengaruh motivasi usaha terhadap keberhasilan usaha, secara statistik akan di uji hipotesis:

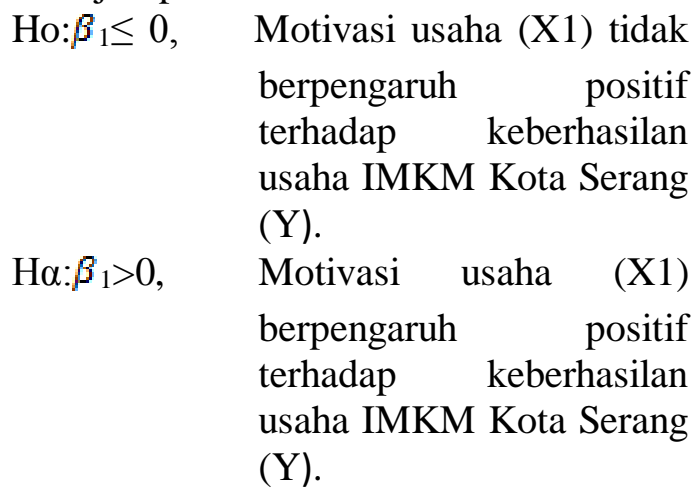

Diperoleh $t_{\text {hitung }}$ pada variabel motivasi Usaha $\left(\mathrm{X}_{1}\right)$ sebesar 4.148 dan nilai $\mathrm{t}_{\text {tabel }}$ untuk $\alpha=0,05$ dengan derajat kebebasan $50-2-1=47$ sebesar 1,677berarti $t_{\text {hitung }}>t_{\text {tabel }}(4.148>$ 1,677). Maka $\mathrm{H} \alpha$ diterima dan $\mathrm{H} 0$ ditolak, artinya faktor motivasi usaha (X1) berpengaruh positif dan signifikan terhadap keberhasilan usaha IMKM Kota Serang (Y).

\section{b) Pengaruh Kemampuan Usaha $\left(\mathbf{X}_{2}\right)$ Terhadap Keberhasilan Usaha (Y) Untuk melihat adanya pengaruh kemampuan usaha terhadap keberhasilan}

usaha, secara statistik akan di uji hipotesis sebagai berikut:

$$
\begin{array}{rlr}
\text { Ho: } \beta_{2} \leq 0 & \text { Kemampuan Usaha }\left(\mathrm{X}_{2}\right) \text { tidak } \\
& \text { berpengaruh terhadap } \\
& \text { Keberhasilan UsahaIMKM } \\
& \text { Kota Serang }(\mathrm{Y}) . \\
\mathrm{H \alpha}: \beta_{2}>0, & \text { Kemampuan Usaha } \\
& \left(\mathrm{X}_{2}\right) \text { berpengaruh positif } \\
& \text { terhadap Keberhasilan Usaha } \\
& \text { IMKM Kota Serang (Y) }
\end{array}
$$

Diperoleh nilai $t_{\text {hitung }}$ pada variabel Kemampuan Usaha $\left(\mathrm{X}_{2}\right)$ sebesar 3.836, dan nilai $t_{\text {tabel }}$ untuk $\alpha=0,05$ dengan derajat kebebasan $50-2-1=47$ sebesar 1,677 berarti $t_{\text {hitung }}>t_{\text {tabel }}(3.836>1,677)$. Maka $\mathrm{H}_{0}$ ditolak dan Ha diterima, artinya kemampuan usaha $\left(\mathrm{X}_{2}\right)$ berpengaruh positif dan signifikan terhadap keberhasilan usaha IMKM Kota Serang (Y).

Analisis Tingkat Harapan dan Tingkat Kinerja (Importance and Performance Analysis/IPA) Keberhasilan Usaha Pada IMKM Makanan Ringan Kota Serang.

Nilai tingkat harapan menggambarkan pentingnya pernyataan tentang motivasi usaha dan kemampuan usaha bagi pemilik usaha.pemilik usaha melakukan penilaian terhadap tingkat harapan dan tingkat kinerja. Pernyataan tersebut yang dinilai adalah motivasi usaha dan kemampuan usaha yakni pernyataan motivasi usaha seperti besar kecilnya laba, kebebasan mengatur usaha, kebebasan mencapai keberhasilan hidup dan rasa bangga dapat mandiri (permodalan dan manajemen). Sedangkan pernyataan kemampuan usaha seperti pengetahuan usaha, memiliki imajinasi dan ide, memiliki pengetahuan praktir dalam disain, pemerosesan, pembukuan, administrasi dan pemasaran, memiliki kreatifitas, memiliki perdiksi, keterampilan berhitung dan keterampilan berkomunikasi.

Tabel 7. Tingkat Harapan Pemilik Usaha Melalui Pendekatan Motivasi Usaha dan Kemampuan Usaha Pada IMKM Makanan Ringan Kota Serang

\begin{tabular}{lll}
\hline No. & Pernyataan & $\begin{array}{c}\text { Rata- } \\
\text { rata }\end{array}$ \\
\hline 1 & Besar kecilnya laba & 4,04
\end{tabular}


2

5
6
7

Memiliki pengetahuan usaha

Memilik imajinasi dan ide

Memiliki pengetahuan praktik

dalam desain, pemrosesan,

pembukuan, administrasi dan

pemasaran

$8 \quad$ Memiliki kreatifitas

3,88

Memiliki prediksi

3,80

10 Memiliki keterampilan berhitung

11 Memiliki keterampilan berkomunikasi

$$
\text { Rata-rata }
$$

3,90

3,94 3,94

Dapat diketahui bahwa penilaian rata-rata tingkat kepentingan (harapan) keseluruhan pernyataan sebesar 3,94 dengan kategori Penting. Ini menunjukan bahwa pernyataan motivasi usaha dan kemampuan usaha dianggpan perlu diperhatikan dalam mencapai keberhasilan usaha.

Setelah pemilik usaha memberikan penilaian mengenai tingkat harapan terhadap pernyataan motivasi usaha dan kemampuan usaha, selanjutnya diminta untuk menilai tingkat kinerja pernyataan-pernyataan tersebut. Nilai tersebut menunjukkan kinerja (persepsi) pemilik usaha terhadap pernyataan motivasi usaha dan kemampuan usaha. Berikut tanggapan pemilik usaha
Gambar 3. Diagram IPA Motivasi Usaha dan

Tabel 8. Tingkat Kinerja Pemilik Usaha

Melalui Pendekatan Motivasi Usaha dan

Kemampuan Usaha Pada IMKM Makanan Ringan Kota Serang

\begin{tabular}{|c|c|c|}
\hline No. & Pernyataan & $\begin{array}{r}\text { Rata- } \\
\text { rata }\end{array}$ \\
\hline 1 & Besar kecilnya laba & 3,44 \\
\hline 2 & Kebebasan mengatur usaha & 3,74 \\
\hline 3 & $\begin{array}{l}\text { Kebebasan mencapai keberhasilan } \\
\text { hidup }\end{array}$ & 3,82 \\
\hline 4 & $\begin{array}{l}\text { Rasa bangga dapat mandiri } \\
\text { (permodalan dan manajemen) }\end{array}$ & 3,60 \\
\hline 5 & Memiliki pengetahuan usaha & 3,60 \\
\hline 6 & Memilik imajinasi dan ide & 3,76 \\
\hline 7 & $\begin{array}{l}\text { Memiliki pengetahuan praktik } \\
\text { dalam desain, pemrosesan, } \\
\text { pembukuan, administrasi dan } \\
\text { pemasaran }\end{array}$ & 3,44 \\
\hline 8 & Memiliki kreatifitas & 3,54 \\
\hline 9 & Memiliki prediksi & 3,66 \\
\hline 10 & Memiliki keterampilan berhitung & 3,80 \\
\hline 11 & $\begin{array}{l}\text { Memiliki keterampilan } \\
\text { berkomunikasi }\end{array}$ & 3,64 \\
\hline & Rata-rata & 3,64 \\
\hline
\end{tabular}

Dapat diketahui bahwa penilaian rata-rata tingkat kinerja keseluruhan pernyataan motivasi usaha dan kemampuan usaha sebesar




3,64 dengan kategori tinggi, menunjukkan tingkat kinerja pada IKM tinggi. Selanjutnya dilakukan analisis IPA. Motivasi usaha dan kemampuan usaha digunakan untuk melihat kedudukan 11 (sebelas) pernyataan yang diperoleh berdasarkan skor tingkat kepentingan/harapan dan tingkat kinerja. Dari hasil rata-rata pada tabel 7 , bahwa nilai $=$

$x$ adalah 3,64, nilai tersebut akan digunakan sebagai batas kuadran pada diagram IPA pada sumbu X. Dan hasil rata-rata pada tabel 8 nilai $\overline{\bar{Y}}$ adalah 3,94, nilai tersebut akan dipakai untuk batas kuadran pada diagram IPA pada sumbu Y. Sehingga menghasilkan diagram kartesius seperti terlihat pada gambar 3 .

Berdasarkan hasil diagram Kartesius hasil dari analisis IPA tersebut bahwa yang perlu diperhatikan oleh pengelola usaha IMKM makanan ringan Kota Serang dan pemerintahan Kota Serang, yakni yang termasuk kuadran pertama (I) yaitu menentukan besar kecilnya laba (1), memiliki rasa bangga dapat mandiri (permodalan dan manajemen), (4) serta memiliki pengetahuan praktik dalam desain, pemrosesan, pembukuan, administrasi dan pemasaran (7).

\section{Penerapan Strategi IMKM Makanan Ringan Kota Serang untuk Peningkatan Keberhasilan Usaha}

Strategi yang bisa diterapkan IMKM Makanan Ringan Kota Serang sesuai dengan diagram IPA adalah sebagai berikut:

1. Kuadran Pertama (I)

Kuadran pertama (I) adalah daerah dimana pernyataan-pernyataan dianggap penting oleh pemilik usaha tapi kenyataannya pernyataan-pernyataan ini belum sesuai seperti pemilik usaha harapkan, yang termasuk kedalam daerah ini adalah besar kecilnya laba (1), rasa bangga dapat mandiri (permodalan dan manajemen) (4), Memiliki pengetahuan praktik dalam disain, pemerosesan, pembukuan, administrasi dan pemasaran (7).

Strategi yang diterapkan adalah melakukan perbaikan secara terusmenerus sehingga performance pernyataan pada kuadran ini akan meningkat (Rangkuti, 2003). Strategi yang dilakukan di IMKM adalah dengan cara memberikan modal tambahan kepada IMKM, memperhitungkan laba dan harga pokok penjualan kembali sehingga meningkatkan laba yang didapatkan, mengadakan pelatihan-pelatihan tentang manajemen seperti praktir dalam membuat disain, pemerosesan dalam berproduksi, pembukuan, administrasi dan pemasaran dan lain-lain, sehingga pemilik usaha IMKM dapat meningkatkan keberhasilan usaha, serta memberikan motivasi kepada pemilik usaha agar dapat ikut serta pelatihan yang direncanakan oleh pemerintahan, karena pemilik usaha masih ada yang tidak mengikuti pelatihan-pelatihan yang diadakan pemerintah.

2. Kuadran Kedua (II)

Menurut Rangkuti (2003) Strategi dalam kuadran ini adalah dengan mempertahankan dan meningkatkan secara terus-menerus agar selalu berada pada kuadan ini dan tidak menurun kinerjanya, dikarenakan pernyataan yang termasuk kuadran ini unggul di mata responden atau pemilik usaha. Pernyataan dikuadran ini adalah Kebebasan mencapai keberhasilan hidup.

3. Kuadran Ketiga (III)

Pada kuadran ini IKM dapat mempertimbangkan kembali peningkatannya, namun dengan tidak menghilangkan pernyataannya, harus dikelola dengan optimal dan maksimal karena biasanya kekecewaan pemilik berawal dari kuadran III (Rangkuti, 2003). Pernyataan di IMKM yang harus dipertahankan adalah memiliki pengetahuan usaha, memiliki kreatifitas dan keterampilan berkomunikasi.

4. Kuadran Keempat (IV)

strategi yang harus diterapkan adalah mengevaluasi semua kegiatan yang berlebihan, sehingga didapatkan bagianbagian mana yang harus dipertahankan dan bagaian-bagian mana yang harus dikurangi sehingga dapat menghemat biaya (Rangkuti, 2003). Pernyataan yang 
dipertimbangkan kembali adalah memiliki imanjinasi dan ide.

\section{KESIMPULAN DAN IMPLIKASI}

Berdasarkan hasil penelitian tentang strategi keberhasilan usaha dengan pendekatan motivasi usaha dan kemampuan usaha pada industri mikro, kecil menengah (IMKM) maknan ringan di Kota Serang, maka dapat disimpulkan:

1) Berdasarkan tanggapan pemilik usaha terhadap motivasi usaha, kemampuan usaha dan keberhasilan usaha: (a) Tanggapan pemilik usaha terhadap motivasi usaha menunjukkan bahwa penilaian atribut kebebasan mencapai usaha adalah tertinggi dengan interprestasi baik, dan atribut dengan penilaian terendah adalah besar kecilnya laba dengan interprestasi tinggi; (b) Tanggapan pemilik usaha terhadap kemampuan usaha menunjukkan bahwa penilaian atribut keterampilan berhitung adalah tertinggi dengan interprestasi baik, sedangkan peneilaian terendah adalah memiliki pengetahuan praktik dalam desain, pemrosesan, pembukuan, administrasi dan pemasaran dengan interprestasi Tinggi; (c) Tanggapan pemilik usaha terhadap keberhasilan usaha menunjukkan bahwa penilaian atribut menjalankan usaha melalui proses adalah tertinggi dengan interprestasi baik, dan penilaian atribut terendah adalah pengelolaan biaya dengan interprestasi baik.

2) Dari hasil pengujian secara simultan (Uji F) bahwa motivasi usaha dan kemampuan usaha secara simultan berpengaruh positif dan signifikan terhadap keberhasilan usaha IMKM makanan ringan di Kota serang.

3) Hasil dari uji secara parsial (Uji t) adalah: (a) Motivasi usaha $\left(\mathrm{X}_{1}\right)$ berpengaruh positif dan signifikan terhadap keberhasilan usaha (Y), (b) Kemampuan usaha $\left(\mathrm{X}_{2}\right)$ berpengaruh positif dan signifikan terhadap keberhasilan usaha (Y).

4) Berdasarkan penilaian pemilik usaha terhadap tingkat harapan dan tingkat kinerja keberhasilan usaha pada IMKM makanan ringan di Kota Serang sesuai hasil dari diagram Importance Performance Analysis (IPA), strategi keberhasilan usaha yang dapat diterapkan adalah : (a) Mempertahankan prestasi yang sudah diraih yakni kebebasan mencapai keberhasilan usaha, (b) Melakukan perbaikan terus menerus seperti menambah modal usaha pada IMKM, memperhitungkan laba dan harga pokok penjualan, sehingga dapat meningkatkan laba atau keuntungan, mengadakan pelatihan-pelatihan tentang manajemen seperti praktir dalam membuat disain, pemerosesan dalam berproduksi, pembukuan, administrasi dan pemasaran dan lain-lain, maka para pelaku IMKM dapat meningkatkan keberhasilan usaha, serta memberikan motivasi kepada pemilik usaha agar dapat mengikuti pelatihan-pelatihan yang diselenggarakan pemerintahan, karena pemilik usaha masih ada yang tidak mengikuti pelatihan.

Adapun saran yang diberikan sebagai berikut: 1) Motivasi usaha dan kemampuan usaha yang sudah dimiliki oleh para pemilik usaha IMKM makanan ringan di Kota Serang, harus dipertahankan dan terus ditingkatkan karena akan berpengaruh terhadap keberhasilan usaha. 2) Keberhsilan usaha yang atributnya masih rendah dalam kinerjanya akan tetapi harapannya sendiri tinggi agar terus diperbaiki, dievaluasi, dan ditingkatkan kinerjanya seperti memiliki pengetahuan praktik dalam desain, pemrosesan, pembukuan, administrasi dan ide, rasa bangga dapat mandiri (permodalan dan manajemen), dan besar kecilnya laba, sehingga dapat meningkatkan keberhasilan usaha. 3) Bagi yang akan melakukan mengenai penelitian lanjutan MSDM di IMKM makanan ringan Kota Serang hendaknya memperdalam kajian mangenai faktor-faktor keberhasilan usaha selain motivasi usaha dan kemampuan usaha, sehingga dapan menjadikan penelitian ini sebagai tambahan data.

\section{DAFTAR PUSTAKA}

Afiah, Nunuy Nur. 2009.Peran Kewirausahaan Dalam Memperkuat UKM 
Indonesia Dalam Menghadapi Krisis Finansial Global, Universitas Padjajaran. Bandung.

Ali Khomsan, 2003. Pangan dan Gizi untuk Kesehatan. PT. Rajagrafindo Persada. Jakarta.

Alifuddin dan Mashur Razak, 2015. Strategi membangun Kerja Bisnis, Magna Script Publishing. Jakarta.

Arikunto S, 2010. Prosedur Penelitian Suatu Pendekatan Praktik. PT. Rineka Cipta. Jakarta.

Badan Pusat Statistik (BPS), 2014. Kriteria Usaha Kecil dan Menengah (UKM).

Direktori Sarana dan Prasarana Penunjang Investasi Kota Serang. Buku Panduan. DISPERINDAGKOP. Kota Serang.

Frankel, J dan Wallen, N. 1993. How to Design and Evaluate Research in Education (2nd ed). Mc Graw-Hill Inc. New York.

Hasibun Melayu, SP. 2000. Manajamen Sumber Daya Manusia Edisi Revisi Ceatakan Kedua. Bumi Aksara. Jakarta.

Irham Fahmi, 2014. Kewirausahaan Teori, Kasus dan Solusi Cetakan Kedua. Alfabeta. Bandung.

Kementerian Koperasi dan UKM. 2012. Perkembangan Data Usaha Mikro, Kecil, dan Menengah (UMKM)/Industri Mikro Kecil dan Menegah (IMKM), dan Usaha Besar (UB) Tahun 2010-2011. (Sumber : http://www.depkop.go.id. didownload Selasa 27-05-2016/23:30).

Leonardus Saiman, 2011. Kewirausahaan Teori, Praktik dan Kasus-kasus. Salemba Empat, Jakarta.

Lestari, Fitria, 2013. Pengaruh Jiwa Kewirausahaan dan Kreativitas Terhadap Keberhasilan Usaha Pada Sentra Industri Rajutan Binong Jati Bandung.

Marzuki, 2001. Metodologi Riset. BPFE UII. Yogyakarta

Mashuri Zainudin, 2008. Metodologi Penelitian Pendekatan Praktis dan Aplikastif, Penerbit PT Refika Aditama. Bandung.
Muchtadi, D. 1998. Kajian Terhadap Serat Makanan dan Antioksida Dalam Berbagai Jenis Sayuran Untuk Pencegahan Penyakit Degneratif. IPB-Press. Bogor.

Muzaki Anta, 2016. Pengaruh Karakteristik, Minat, dan Motivasi Wirausaha Terhadap Keberhasilan Usaha Pada UMKM Desa Jarak Kecamatan Plosoklaten Kabupaten Kediri. Universitas Nusantara. Kediri.

Purnama Chamdan, 2010. Motivasi dan Kemampuan Usaha Dalam Meningkatkan keberhasilan Usaha Industri Kecil (Studi Pada Industri Kecil Spatu di Jawa Timur). Universitas Dr. Soetomo. Surabaya

Rusdiana, 2014. Kewirausahaan Teori dan Praktik Cetakan Pertama. Pustaka Setia. Bandung.

Singarimbun, Masri dan Tri Handayani. 1989. "Pembuatan Kuesioner", dalam Masri Singarimbun dan Sofian Efendi (eds.) Metode Penelitian Survai. LP3ES. Jakarta.

Sugiyono, 2013. Metode Pendidikan Penelitian. Alfa Beta. Bandung , 2014. Metode Penelitian Kuantitatif, Kualitatif, dan Kombinasi (Mix Methods). CV Alfabet. Jakarta.

Sunyoto, Danang. 2012. Manajemen Sumber Daya Manusia, Caps. Suryana. Yogyakarta

Suparno, E. Widodo. 2015. Manajemen Pengembangan Sumber Daya Manusia Cetakan Pertama. Pustaka Pelajar. Yogyakarta.

Supranto, J. 2001. Pengukuran Tingkat Kepuasan Pelanggan Untuk menakan Pangsa Pasar. Rineka Cipta. Jakarta.

Suryana dan Bayu, 2013. Kewirausahaan Kiat dan Proses Menuju Sukses Edisi Keempat. Salemba Empat. Jakarta.

Tulus Tambunan 2009. UMKM di Indonesia. Ghalia Indonesia. Bogor.

Undang-Undang Republik Indonesia Nomor 20 Tahun 2008 (Sumber: http://www.depkop.go.iddidownload kamis 09-06-2016/21:45) 
Yuyus Suryana dan Kartib Bayu, Wirman, Syafri dan Alwi, 2014.Manajemen 2013.Kewirausahaan. Pendekatan Karakteristik Wirausahaan Sukses. Sumber Daya Manusia Dalam Edisi Kedua. Penerbit. Kencana Organisasi Publik, IPDN PRESS, Prenada Media Group. Jakarta. Sumedang. 